\title{
New records of Euglenophyta from Korea
}

\author{
Han Soon Kim* \\ Department of Biology, Kyungpook National University, Daegu 702-701, Korea
}

\begin{abstract}
The present study summarized the occurrence, distribution and autecology of 18 taxa in the class Euglenophyceae collected from several swamps, reservoir and mountain wetlands in the South Korea from 2009 to 2013 . This paper deals with 18 taxa consisting of 3 taxa of Colacium Ehrenberg, 2 taxa of Phacus Dujardin, 13 taxa of Trachelomonas Ehrenberg, which are recorded for the first time in Korean freshwater algal flora.
\end{abstract}

Key words: Colacium, Euglenophyceae, Phacus, Trachelomonas

\section{INTRODUCTION}

Since Kawamura (1918) reported a species of Centritractus at lake Seoho, Suwon, to date, about 1,800 taxa of freshwater algae have been recorded in Korea, excluding diatoms (Chung 1968, Chung 1970, 1975, 1976, 1979, 1993, Chung et al. 1972a, 1972b, Chung and Lee 1986, Wui and Kim 1987a, 1987b, Kim 1993, 1996, Kim and Chung 1993, 1994, Kim et al. 2009). About 210 taxa of Euglenophytes have been recorded in Korea. However, this is only $23 \%$ of the 900 species of Euglenophytes reported throughout the world (Van den Hoek et al. 1995, John et al. 2011). The most floristic or taxonomic studies of Euglenophytes from Korea have been conducted along with other taxonomic groups of freshwater algae, and only a few studies considering only Euglenophytes flora have been carried out from Korea (Chung and Chang 1957, Chung 1975, Wui and Kim 1987a, Chung and Kim 1992, 1993).

The importance of biological diversity has been emphasized, and the discovery of indigenous species for securing the sovereignty over biological resources is recognized as an urgent national task. Therefore, freshwater algae investigations in uninvestigated regions in Korea including unusual environments (e.g., highland moorlands, mountain sphagnum bogs or wetlands and craters) are required immediately.

More than 500 samples were collected from various water bodies throughout the country and were investigated to establish freshwater algal flora in Korea. This study reports 18 species of Euglenophytes for the first time in Korea.

\section{MATERIALS AND METHODS}

Over 500 samples were collected from various types of wetland habitats ranging from eutrophic reservoirs and diverse swamps to oligotrophic and acidic mountainous wetlands, sphagnum bogs, orum (very small and shallow caldera lakes) from 2009 to 2013 (Fig. 1). The samples were obtained by plankton net (mesh size $25 \mu \mathrm{m}$ ), spoid or by squeezing submerged macrophytes. Living material was examined immediately. After the initial examination, all materials were fixed with 5\% formalin for permanent preservation and detail identification. Microscopic examinations were made at $\times 200$ to $\times 1,000$ magnification with an Axio Imager microsope (A2; Carl Zeiss, Oberkochen, Germany), and photographs were taken with an AxioCam http://dx.doi.org/10.5141/ecoenv.2013.339

\footnotetext{
cC) (1) This is an Open Access article distributed under the terms of the Creative Commons Attribution Non-Commercial Licens (http://creativecommons.org/licenses/by-nc/3.0/) which permits unrestricted non-commercial use, distribution, and reproduction in any medium, provided the original work is properly cited.
}

Received 29 October 2013, Accepted 22 November 2013

*Corresponding Author

E-mail: kimhsu@knu.ac.kr

Tel: +82-53-950-5344 


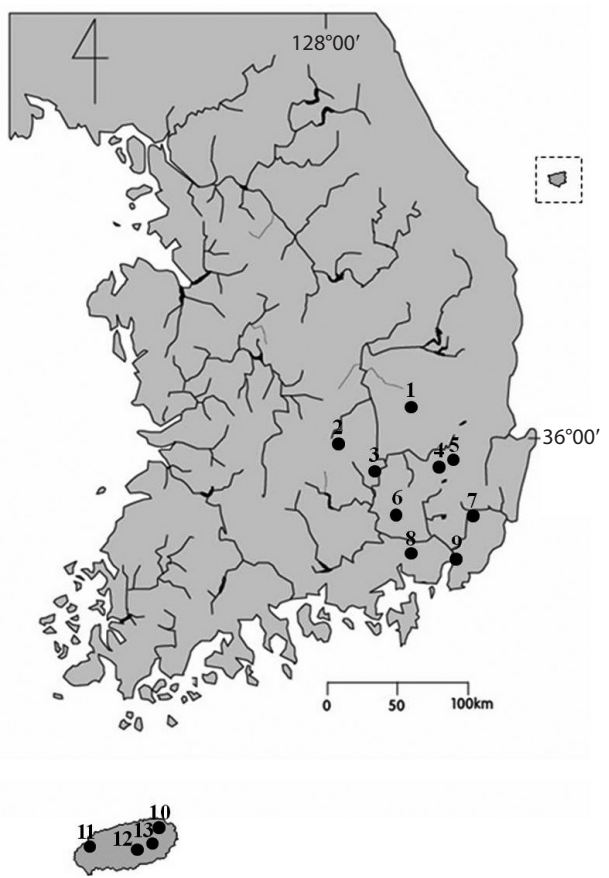

Fig. 1. Location of sampling sites in the territory of Korea. Numbers on the map represent as follow: 1, Gaecheon reservoir; 2, Deonghyen reservoir; 3, Jinchon swamp; 4, Bujae reservoir; 5, Guryong reservoir; 6, Jangcheok reservoir; 7, Mujechineup; 8, Junam reservoir; 9, Samlak wet-lands; 10, Dongbaek-dongsan; 11, Dumo reservoir; 12, Mulyoungari oreum; 13, Micheongul. See detailed information of sampling site in Table 1.
HRC camera (Carl Zeiss). Water temperature, pH, and conductivity were measured in the field with a HI8314 membrane $\mathrm{pH}$ meter (Hanna instruments, Smithfield, RI, USA) and a HI9835 EC meter (Hanna instruments). 18 species of Euglenophyta, which have not previously been recorded from Korea, are described and illustrated with photographs. The materials were deposited at the National Institute of Biological Resources (NIBR) and Department of Biology, Kyungpook National University.

\section{RESULTS AND DISCUSSION}

\section{Euglenophyceae \\ Euglenales \\ Colaciaceae}

Colacium mucronatum Bourrelly et Chadefaud (Fig. 2G)

References: Huber-Pestalozzi 1955, p 134, pl. 25, fig. 115a-c; Tell and Conforti 1986, p 182, fig. 428 a-c; Yamagishi and Akiyama 1989a, p 12.

Description: Cells 12-13 $\mu \mathrm{m}$ in diameter, $16-18 \mu \mathrm{m}$ long, ovoid or fusiform, rounded at anterior end and with a papilla-like small projection at the posterior end,

Table 1. Sampling date and environmental factors of the sampling sites

\begin{tabular}{|c|c|c|c|c|c|c|}
\hline No. & Sampling sites & Date & WT $\left({ }^{\circ} \mathrm{C}\right)$ & $\mathrm{pH}$ & $\mathrm{EC}(\mu \mathrm{S} / \mathrm{cm})$ & Altitude (m) \\
\hline 1 & $\begin{array}{l}\text { Gaecheon reservoir } \\
\left(128^{\circ} 28^{\prime} 00^{\prime \prime} \mathrm{E}, 36^{\circ} 23^{\prime} 00^{\prime \prime} \mathrm{N}\right)\end{array}$ & 26 Aug 2009 & 24.8 & 7.7 & 98 & 110 \\
\hline 2 & $\begin{array}{l}\text { Deonghyen reservoir } \\
\left(129^{\circ} 13^{\prime} 00^{\prime \prime} \mathrm{E}, 36^{\circ} 03^{\prime} 30^{\prime \prime} \mathrm{N}\right)\end{array}$ & 15 Mar 2013 & 18.2 & 75 & 135 & 250 \\
\hline 3 & $\begin{array}{l}\text { Jinchon swamp } \\
\left(128^{\circ} 25^{\prime} 40^{\prime \prime} \mathrm{E}, 35^{\circ} 42^{\prime} 50^{\prime \prime} \mathrm{N}\right)\end{array}$ & 30 Aug 2009 & 27.5 & 8.2 & 417 & 15 \\
\hline 4 & $\begin{array}{l}\text { Bujae reservoir } \\
\left(128^{\circ} 53^{\prime} 00^{\prime \prime} \mathrm{E}, 35^{\circ} 47^{\prime} 30^{\prime \prime} \mathrm{N}\right)\end{array}$ & 18 Aug 2009 & 29 & 7.7 & 213 & 160 \\
\hline 5 & $\begin{array}{l}\text { Guryong reservoir } \\
\left(128^{\circ} 58^{\prime} 05^{\prime \prime} \mathrm{E}, 35^{\circ} 49^{\prime} 55^{\prime \prime} \mathrm{N}\right)\end{array}$ & 15 Oct 2009 & 31 & 6.57 & 127 & 560 \\
\hline 6 & $\begin{array}{l}\text { Jangcheok reservoir } \\
\left(128^{\circ} 29^{\prime} 05^{\prime \prime} \mathrm{E}, 35^{\circ} 26^{\prime} 10^{\prime \prime} \mathrm{N}\right)\end{array}$ & 20 Aug 2011 & 25 & 7.4 & 103 & 10 \\
\hline 7 & $\begin{array}{l}\text { Mujechineup } \\
\left(128^{\circ} 53^{\prime} 00^{\prime \prime} \mathrm{E}, 35^{\circ} 47^{\prime} 30^{\prime \prime} \mathrm{N}\right)\end{array}$ & 22 Sep 2010 & 25.1 & 6.5 & 21 & 650 \\
\hline 8 & $\begin{array}{l}\text { Junam reservoir } \\
\left(128^{\circ} 39^{\prime} 50^{\prime \prime} \mathrm{E}, 35^{\circ} 18^{\prime} 35^{\prime \prime} \mathrm{N}\right)\end{array}$ & 20 Aug 2011 & 28.5 & 6.8 & 197 & 10 \\
\hline 9 & $\begin{array}{l}\text { Samlak wet-lands } \\
\left(128^{\circ} 58^{\prime} 20^{\prime \prime} \mathrm{E}, 35^{\circ} 10^{\prime} 40^{\prime \prime} \mathrm{N}\right)\end{array}$ & 17 July 2011 & 30.5 & 6.0 & 120 & 5 \\
\hline 10 & $\begin{array}{l}\text { Dongbaek-dongsan } \\
\left(126^{\circ} 44^{\prime} 10^{\prime \prime} \mathrm{E}, 33^{\circ} 31^{\prime} 06^{\prime \prime} \mathrm{N}\right)\end{array}$ & 10 Sep 2009 & 27.5 & 6.1 & 57 & 10 \\
\hline 11 & $\begin{array}{l}\text { Dumo reservoir } \\
\left(126^{\circ} 11^{\prime} 20^{\prime \prime} \mathrm{E}, 33^{\circ} 21^{\prime} 23^{\prime \prime} \mathrm{N}\right)\end{array}$ & 17 Oct 2007 & 26.6 & 7.8 & 359 & 10 \\
\hline 12 & $\begin{array}{l}\text { Mulyoungari oreum } \\
\left(126^{\circ} 41^{\prime} 20^{\prime \prime} \mathrm{E}, 33^{\circ} 22^{\prime} 50^{\prime \prime} \mathrm{N}\right)\end{array}$ & 09 Sep 2009 & 24.5 & 5.6 & 36 & 490 \\
\hline 13 & $\begin{array}{l}\text { Micheongul(Small pond) } \\
\left(126^{\circ} 50^{\prime} 18^{\prime \prime} \mathrm{E}, 33^{\circ} 23^{\prime} 05^{\prime \prime} \mathrm{N}\right)\end{array}$ & 10 Sep 2009 & 25.3 & 6.1 & 28 & 110 \\
\hline
\end{tabular}

Note: WT, water temperature; EC, electronical conductivity. 

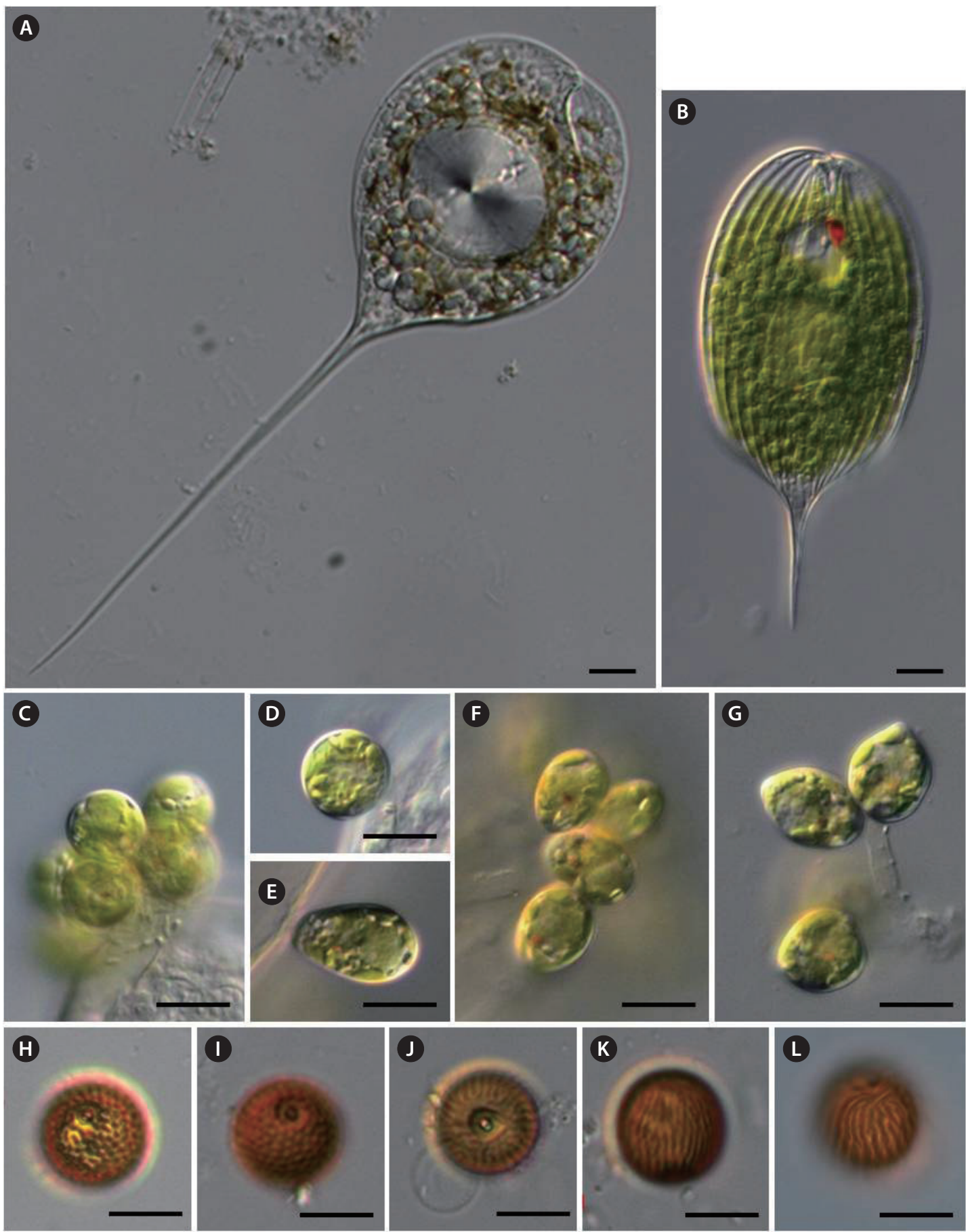

Fig. 2. (A) Phacus longicauda var. major, (B) P. ranula, (C-D) Colacium simplex, (E-F) C. vesiculosum, (G) C. mucronatum, (H-I) Trachelomonas verrucosa var. irregularis, (J-L) T. stokesiana. Scale bars, $10 \mu \mathrm{m}$.

attached by dichotomously branched mucilaginous gelatinous stalks; periplast thin and spiral, chloroplast discshaped, 6-8 in number, each with an inner pyrenoid; usually growing as sessile colonies on freshwater zooplankton such as Cyclops or Copepoda.

This species is probably cosmopolitan, and rarely oc- curs in reservoirs, ponds, ditch and swamps where usually attached to Crustacea, copepods and rotifers.

Occurrence: Collected at Guryong reservoir.

Colacium simplex Ehuber-Pestalozzi (Fig. 2C and 2D)

References: Huber-Pestalozzi 1955, p 123, pl. 23, fig. 
107a-d; Shi 1999, p 90, pl. 31, figs. 6-8.

Description: Cells $12-13 \mu \mathrm{m}$ in diameter, ovoid or subspherical, solitary or colony of two to several cells attached to substratum by a pillow-like mucilaginous cushion; usually growing as sessile colonies on freshwater zooplankton such as Keratella.

This species reported in Romania, Turkey and China and usually occurs in reservoirs, ponds, ditches and swamps where usually attached to Crustaceae, copepods and rotifers.

Occurrence: Collected at Guryong reservoir.

\section{Colacium vesiculosum Ehrenberg (Fig. 2E and 2F)}

References: Huber-Pestalozzi 1955, p 127, pl. 24, fig. 112a-h; Tell and Conforti 1986, p 183, fig. 430a-c; Yamagishi and Akiyama 1989a, p 13; John et al. 2011, p 184, pl. 54, fig. T-W.

Description: Cells $12-13 \mu \mathrm{m}$ in diameter, 18-20 $\mu \mathrm{m}$ long, ovoid or fusiform with rounded posterior end, solitary or forming dendroid colonies of two, four or eight cells attached by a short, unbranched mucilaginous stalk or dichotomously branched gelatinous stalks; usually growing as sessile colonies on freshwater zooplankton such as Cladocera or Coprpoda.

This species is distributed worldwide and usually occurs in reservoirs, ponds, ditches and swamps where it is usually attached to Crustaceae, copepods and rotifers.

Occurrence: Collected at Guryong reservoir.

\section{Euglenales \\ Phacaceae}

\section{Phacus longicauda var. major Swirenko (Fig. 2A)}

References: Huber-Pestalozzi 1955, p 223, pl. 49, fig. 302; Yamagishi and Akiyama 1989b, p 60; Shi 1999, p 233, pl. 71 , fig. 2 .

Description: Cells broadly ovoid to ellipsoid, nearly symmetrical, anterior end broadly rounded, shallowly bilobed; posterior end narrowed and tapering into a cauda; caudae long, nearly straight or slightly curved; lateral margins broadly rounded; paramylon bodies usually a single, large ring-like or circular plate; periplasts longitudinally roughly striated; cell length 170-185 $\mu \mathrm{m}$ with cauda, 70-75 $\mu \mathrm{m}$ without cauda, diameter 55-65 $\mu \mathrm{m}$. This species distributed worldwide and usually occurs in reservoirs, ponds and swamps where the freshwater is mineralized or has high humic content.

Occurrence: Collected at Samlak wet-lands, Guryong reservoir and Jangcheok reservoir.

\section{Phacus ranula Pochmann (Fig. 2B)}

References: Huber-Pestalozzi 1955, p 227, pl. 52, fig. 313a-e; Yamagishi and Akiyama 1985, p 65; Shi 1999, p 234, pl. 72, fig. 5.

Description: Cells 45-55 $\mu \mathrm{m}$ in diameter, 75-85 $\mu \mathrm{m}$ long without cauda, caudae 25-35 $\mu \mathrm{m}$, broadly fusiform to ellipsoid, anterior end slightly narrowed and rounded, posterior end narrowed and tapering into a cauda; caudae about one third of cell length, straight, sharply pointed, sometimes recurved at end; lateral margins broadly rounded; periplasts longitudinally striated; paramylon bodies two to several, circular plate-like.

This species distributed worldwide and usually occurs in reservoirs, ponds and swamps where the freshwater is mineralized or has high humic content.

Occurrence: Collected at Junam reservoir, Samlak wetlands and Jangcheok reservoir.

\section{Euglenaceae}

Trachelomonas armata var. longa Deflandre 1926 (Fig. 3A)

References: Huber-Pestalozzi 1955, p 310, pl. 67, fig. 591; Yamagishi and Akiyama 1995a, p 71.

Description: Lorica 29-31 $\mu \mathrm{m}$ in diameter, $40-43 \mu \mathrm{m}$ long; posterior spines 10-15 $\mu \mathrm{m}$ long, long broad-ovoid; anterior and posterior ends broadly rounded; lateral sides nearly straight and parallei; flagellum apertures without a collar; wall densely punctuate, roughly beset with short spines at the anterior end and stout long spines at the posterior end.

This species is distributed worldwide and commonly occurs in mesotrophic to eutrophic reservoirs, ponds and swamps.

Occurrence: Collected at Gaecheon reservoir, Mulyoungari, Guryong reservoir, Samlak wet-lands and Jangcheok reservoir.

Trachelomonas armata var. ovata D.O. Swirenko (Fig. 3D)

References: Huber-Pestalozzi 1955, p 310, pl. 68, fig. 593; Yamagishi and Akiyama 1987a, p 89.

Description: Lorica 30-33 $\mu \mathrm{m}$ in diameter, 40-46 $\mu \mathrm{m}$ long; posterior spines 15-25 $\mu \mathrm{m}$ long, broadly ovoid; anterior end slightly truncate, posterior end broadly rounded; lateral sides swelled; flagellum apertures with or without a low collar but surrounded by a circle of short spines; anterior parts of wall beset with many short, stout spines and posterior parts with long, stout spines.

This species is distributed worldwide and commonly 

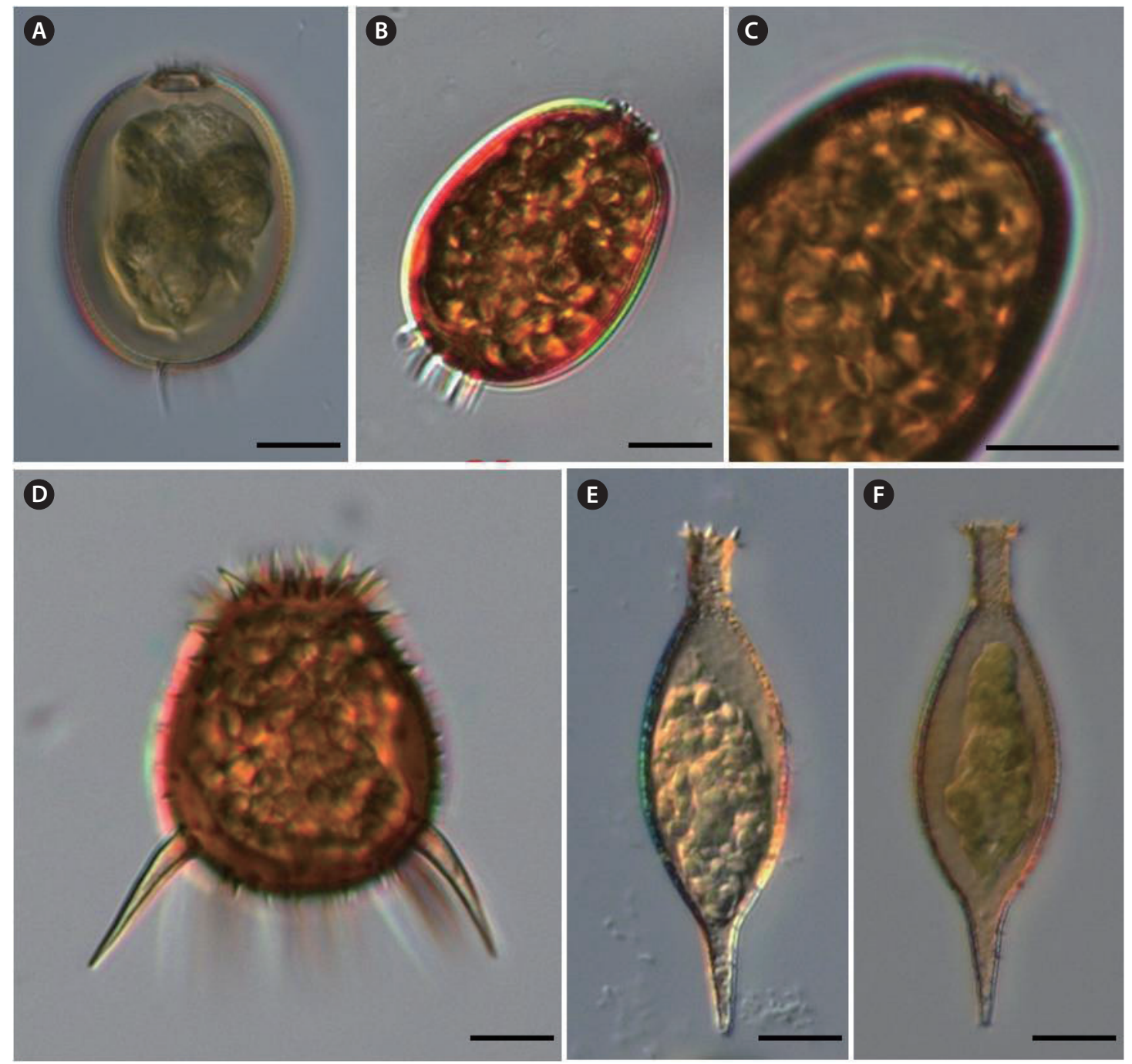

Fig. 3. (A) Trachelomonas armata var. longa, (B-C) T. armata var. rangpurens, (D) T. armata var. ovata, (E-F) T. nadsonii. Scale bars, $10 \mu \mathrm{m}$.

occurs in mesotrophic to eutrophic reservoirs, ponds and swamps.

Occurrence: Collected at small pond near the Micheongul, Mulyoungari and Guryong reservoir.

\section{Trachelomonas armata var. rangpurens Islam \& Mu-} niruzzaman (Fig. 3B and 3C)

Reference: Yamagishi and Akiyama 1995a, p 72.

Description: Lorica $28-30 \mu \mathrm{m}$ in diameter, $34-37 \mu \mathrm{m}$ long, posterior spines $6-8 \mu \mathrm{m}$ long, broad-ellipsoid to ovoid; anterior and posterior ends rounded; lateral sides broadly swelled; flagellum apertures without a clear collar, but encircled by 4-6 short, curved stout spines; wall finely punctate, with 4-8 long, curved, stout spines at the posterior portion.

This species is distributed worldwide and usually oc- curs in mesotrophic to eutrophic reservoirs, ponds and swamps.

Occurrence: Collected at Guryong reservoir.

\section{Trachelomonas arnoldina var. decurtata Skvortzov (Fig.} 4I)

References: Huber-Pestalozzi 1969, p 332, pl. 71, fig. 686; Yamagishi and Akiyama 1987b, p 92.

Description: Lorica $24-26 \mu \mathrm{m}$ in diameter, $29-31 \mu \mathrm{m}$ long without the collar; collar 3.4-4.5 $\mu \mathrm{m}$ wide, $4-5 \mu \mathrm{m}$ long, broad-ovoid; anterior ends slight narrowly rounded, posterior end broadly rounded, lateral sides broadly rounded; flagellum apertures with a long, cylindric collar having a irregular or serrated and flared mouth; wall densely punctate.

This species is distributed worldwide and usually oc- 
curs in mesotrophic to eutrophic reservoirs, ponds and swamps.

Occurrence: Collected at Dumo reservoir.

\section{Trachelomonas baikovii Skvortzov (Fig. 4J)}

References: Huber-Pestalozzi 1955, p 357, pl. 76, fig. 773; Shi 1999, p 148, pl. 42, fig. 10.

Description: Lorica $48-52 \mu \mathrm{m}$ long, $23-25 \mu \mathrm{m}$ in diameter, collar 4-5 $\mu \mathrm{m}$ long, cauda 7-8 $\mu \mathrm{m}$ long, ellipsoid to fusiform; anterior end gradually narrowed into a cylindrical collar; posterior end conically narrowed into a conical cauda with several short spines at the end; flagellum apertures with a cylindric collar having a crown of some short spines around the mouth; wall covered with conical short spines. This species reported in Europe and China.

Occurrence: Collected somewhat abundantly at mesotrophic Samlak wetl-ands.

\section{Trachelomonas bernardii Woloszynska (Fig. 4A)}

References: Huber-Pestalozzi 1955, p 270, pl. 59, fig. 432; Yamagishi and Akiyama 1995a, p 74; Shi 1999, p 108, pl. 34 , fig. 5 .

Description: Lorica 11-12 $\mu \mathrm{m}$ long, $15-16 \mu \mathrm{m}$ in diameter, compressed globose; transversely ellipsoid with rounded sides in lateral view, circular in vertical view; flagellum apertures without a collar; wall smooth.

This species is distributed worldwide and usually occurs in mesotrophic to eutrophic reservoirs, ponds and swamps.

Occurrence: Collected at Gaecheon reservoir, Guryong reservoir, Junam reservoir and Samlak wet-lands.

Trachelomonas globularia var. gigas Drezepolski (Fig. 4D and 4E)

References: Huber-Pestalozzi 1955, p 268, pl. 57, fig. 379; Yamagishi and Akiyama 1995a, p 72.

Description: Lorica globose, $27-30 \mu \mathrm{m}$ in diameter without spines, spines $4-5 \mu \mathrm{m}$ long; flagellum apertures without a collar; wall covered with micro-puncta and long, stout, sharp conical spines. Cells more large than in the nominate variety.

This species is distributed worldwide and usually occurs in mesotrophic to eutrophic reservoirs, ponds and swamps.

Occurrence: Collected at Guryong reservoir, Samlak wet-lands and Junam reservoir.

Trachelomonas helvetica var. cucurbita (Skvortzov) Huber-Pestalozzi (Fig. 4G and 4H)

Reference: Huber-Pestalozzi 1955, p 356, pl. 76, fig. 771.
Description: Lorica 35-37 $\mu \mathrm{m}$ long, $13-15 \mu \mathrm{m}$ in diameter, ellipsoidal or ovoid, anterior end rounded, posterior end tapered into a conical short cauda; flagellum apertures wide, without a collar, but encircled by 6-8 short spines; wall covered with conical short spines. The variety differs from the nominal by a higher length/breadth ratio and with narrower width.

This species has been reported only in Europe and rarely occurs in mesotrophic to eutrophic reservoirs, ponds and swamps.

Occurrence: Collected at Samlak wet-lands.

Trachelomonas mirabilis var. affinis Skvortzov (Fig. 4F)

References: Huber-Pestalozzi 1955, p 312, pl. 68, fig. 601; Yamagishi and Akiyama 1987b, p 92; Shi 1999, p 141, pl. 41 , fig. 3 .

Description: Lorica $20-22 \mu \mathrm{m}$ in diameter, $31-33 \mu \mathrm{m}$ long with collar, collar 3-5 $\mu$ m long, broadly fusiform, anterior and posterior ends narrowly rounded, lateral sides swelled; flagellum apertures with a cylindric collar having a circle of stout spines at mouth; wall covered with many short, stout spines.

This species is distributed worldwide and usually occurs in mesotrophic to eutrophic reservoirs, ponds and swamps.

Occurrence: Collected at Guryong reservoir, Jangcheok reservoir, Junam reservoir and Samlak wet-lands.

\section{Trachelomonas nadsonii Skvortzov (Fig. 3E and 3F)}

Reference: Huber-Pestalozzi 1955, p 358, pl. 76, fig. 774.

Description: Lorica 16-18 $\mu \mathrm{m}$ in diameter, 55-60 $\mu \mathrm{m}$ long with collar and caudal projection, collar $4-5 \mu \mathrm{m}$ wide, 7-9 $\mu \mathrm{m}$ long; posterior cauda 10-12 $\mu \mathrm{m}$ long, narrow-ellipsoid to fusiform; anterior end conically narrowed into a cylindrical collar; posterior end conically narrowed into a conical cauda; flagellum apertures with a long, cylindrical collar having several short spines around the mouth; wall punctuate, covered with sparsely scattered short spines.

This species has been reported in Europe and China and rarely occurs in mesotrophic to eutrophic reservoirs, ponds and swamps.

Occurrence: Collected at Samlak wet-lands.

\section{Trachelomonas sculpta Balech (Fig. 4B and 4C)}

References: Huber-Pestalozzi 1955, p 263, pl. 58, fig. 400B; Yamagishi and Akiyama 1995b, p 94.

Description: Lorica spherical, $17-20 \mu \mathrm{m}$ in diameter; flagellum apertures (2-2.5 $\mu \mathrm{m}$ in diameter) surrounded by an annular thickening; wall reddish-brown, ornamented with polygonal depressions, closely distributed. 

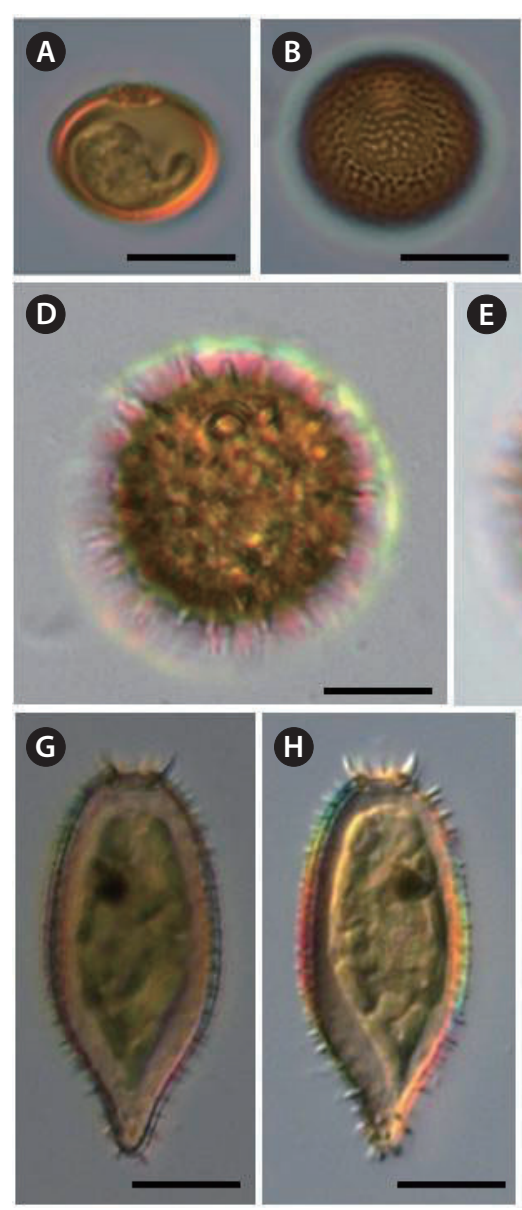

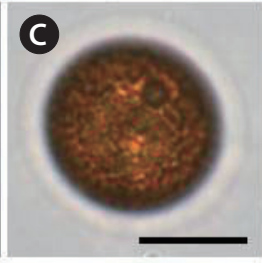

E
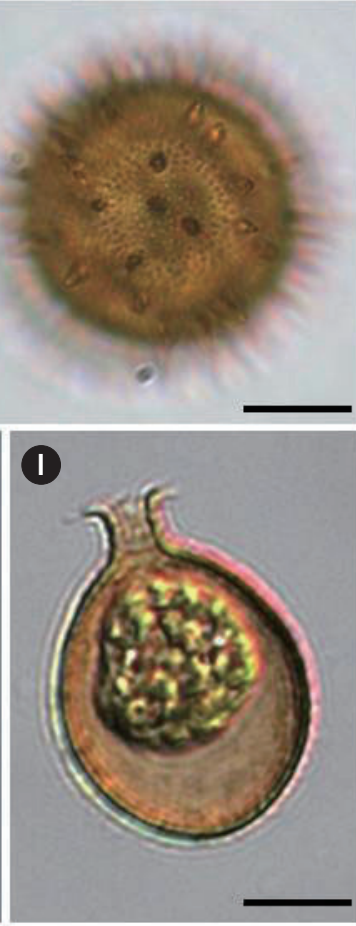
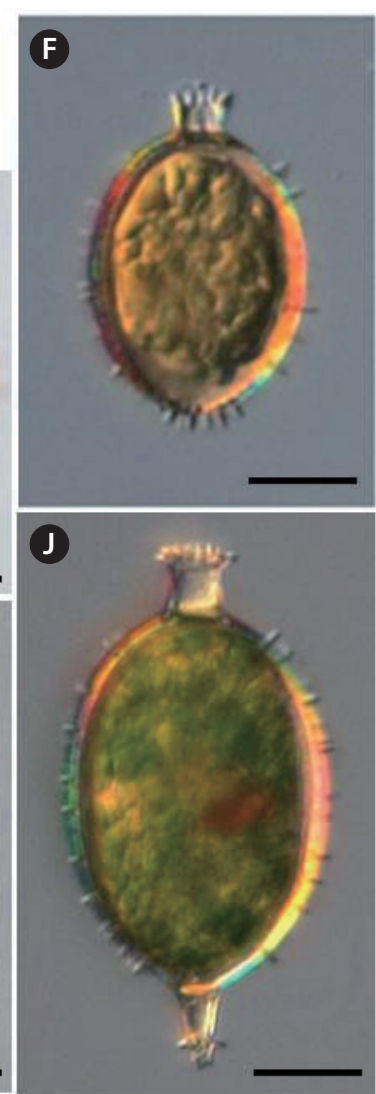

Fig. 4. (A) Trachelomonas bernardii, (B-C) T. sculpta, (D-E) T. globularia var. gigas, (F) T. mirabilis var. affinis, (G-H) T. helvetica var. cucurbita, (I) T. arnoldina var. decurtata, (J) T. baikovii. Scale bars, $10 \mu \mathrm{m}$.

This species is distributed worldwide and usually occurs in mesotrophic to eutrophic reservoirs, ponds and swamps.

Occurrence: Collected at Gaecheon reservoir, Guryong reservoir, Jangcheok reservoir, Junam reservoir and Samlak wet-lands.

\section{Trachelomonas stokesiana Palmer (Fig. 2J-2L)}

References: Huber-Pestalozzi 1955, 264, pl. 58, fig. 407a-c; Yamagishi and Akiyama 1989a, p 95; Shi 1999, p 105, pl. 33, fig. 9.

Description: Lorica 17-18 $\mu \mathrm{m}$ long, $15-16 \mu \mathrm{m}$ in diameter, globose to subglobose, slightly longer than the diameter; flagellum apertures with a short cylindrical collar; collars bluntly conical seated in a shallow circular depression; wall ornamented with conspicuous, distinct, occasionally anastomosing, continuous ridge, obliquely longitudinal on the side, nearly spiral at the ends.

This species is distributed worldwide and usually oc- curs in mesotrophic to eutrophic reservoirs, ponds and swamps.

Occurrence: Collected at Gaecheon reservoir, Guryong reservoir, Jangcheok reservoir, Junam reservoir and Samlak wet-lands.

\section{Trachelomonas verrucosa var. irregularis Deflandre (Fig.} 2H and 2I)

References: Huber-Pestalozzi 1955, p 263, pl. 58, fig. 400B; John et al. 2011, p 226, pl. 57, figs. N, O.

Description: Lorica spherical, diameter 12.5-14 $\mu \mathrm{m}$; flagellum apertures without a collar, surrounded by an annular thickening; wall reddish-brown, ornamented with close, irregular small warts or granules.

This species has been reported in Europe and North America and commonly occurs in mesotrophic to eutrophic reservoirs, ponds and swamps.

Occurrence: Collected at Dumo reservoir, Guryong reservoir, Junam reservoir and Samlak wet-lands. 


\section{CONCLUSION}

In this study, 18 species of Euglenophyceae were newly added to the Korean freshwater algal flora.

\section{ACKNOWLEDGMENTS}

This work was supported by a grant from the National Institute of Biological Resources (NIBR), funded by the Ministry of Environment (MOE) of the Republic of Korea (NBIR No. 2013-01-001).

\section{LITERATURE CITED}

Chung J. 1970. A taxonomic study on the Fresh-water algae from Youngnam area. PhD Dissertation. Kyungpook National University, Daegu, Korea. (in Korean)

Chung J. 1975. A study on the Euglenophyceae from Chon La Book Do area. Res Rev Kyungpook Natl Univ 20: 233242. (in Korean with English abstract)

Chung J. 1976. A study on the Cyanophyceae from Chun Ra Book Do area. Kor J Bot 19: 19-30. (in Korean with English abstract)

Chung J. 1979. A study on the Fresh-water algae from Chungchong Book Do area. Korean J Limnol 12: 41-53. (in Korean with English abstract)

Chung J. 1993. Illustrations of the Korean freshwater algae. Academy Publishing co., Seoul. (in Korean)

Chung J, Kim HS. 1992. Fresh-water algae new to Korea (II). Kor J Phycol 7: 173-183. (in Korean with English abstract)

Chung J, Kim HS. 1993. Fresh-water algae new to Korea (III). Kor J Phycol 8: 37-46.

Chung J, Kim SD, Lee KS. 1972a. Fresh-water algae from Jeju Ju Do Island (I). Korean J Limnol 5(1): 13-23.

Chung J, Kim SD, Lee KS. 1972b. Fresh-water algae from Jeju Ju Do Island (II). Korean J Limnol 5(3): 15-31.

Chung YH. 1968. Illustratied Encylopedia of Fauan and Flora of Korea, Vol. 9. Fresh Water Algae. Samwha Publishing, Seoul. (in Korean)

Chung YH, Lee OM. 1986. A taxonomic study of desmids on several lowland swamp in Haman. Proc Coll Nat Sci Seoul Natl Univ 11: 51-98.

Chung YH, Chang YK. 1957. A study on Euglena in the area of Seoul (II). Univ Seoul Coll Thesis Sci Nat 5: 119-128.

Huber-Pestalozzi G. 1955. Das Phytoplankton des Süßwassers. Euglenophyceen. In: Die Binnengewässer 16(4) (Thienemann, A, ed). Schweiz Verg, Stuttgart.
John DM, Whitton BA, Brook AJ. 2011. The freshwater algal flora of the British Isles. 2nd ed. Cambridge University Press, Cambridge.

Kawamura T. 1918. Freshwater biology of Japan. 1st ed. Shokabo, Tokyo. (in Japanese)

Kim HS. 1992. Taxonomic and Ecological studies of freshwater algae on natural swamps and reservoirs at Changnyong County Area. PhD Dissertation. Kyungpook National University, Daegu, Korea. (in Korean with English abstract)

Kim HS. 1996. Desmids (Staurastrum and Staurodesmus) from Kyongsangnam-Do, Korea. Nova Hedwigia 62: 521-541.

Kim HS, Chung J. 1993. Freshwater algal flora of natural swamps in Chnagnyong County. Korean J Limnol 26: 305-319. (Korean with English abstract)

Kim HS, Chung J. 1994. Fresh-water algae new to Korea (IV). Kor J Phycol 9: 1-6.

Kim JH, Park YJ, Kim HS. 2009. Silica-scaled chrysophytes (Synurophyceae) from Jeju Island, Korea. Nova Hedwigia 89: 201-218.

Shi ZX. 1999. Flora Algarum Sincarus Aquae Dulcis, Vol. 6, Euglenophyta. Science Press, Beijing. (in Chinese with keys in English)

Tell G, Conforti V. 1986. Euglenophyta pigmentadas de la Argentina, Bibliotheca Phycologica 75. J Cramer, Berlin.

Van den Hoek C, Mann DG, Jahns HM. 1995. Algae: An introduction to phycology. Cambridge University Press. Cambridge.

Wui IS, Kim BH. 1987a. The Flora of the Fresh-Water Algae in Chol La Nam Do, Korea (I) Euglenophyceae. Kor J Phycol 2: 119-127.

Wui IS, Kim BH. 1987b. Flora of the Fresh-Water Algae in Chol La Nam Do, Korea (II) Cyanophyceae. Kor J Phycol 2: 193-201.

Yamagishi T, Akiyama M. 1985. Photomicrographs of the Fresh-water algae. Vol. 4. Uchida Rokakuho, Tokyo.

Yamagishi T, Akiyama M. 1987a. Photomicrographs of the Fresh-water algae. Vol. 6. Uchida Rokakuho, Tokyo.

Yamagishi T, Akiyama M. 1987b. Photomicrographs of the Fresh-water algae. Vol. 7. Uchida Rokakuho, Tokyo.

Yamagishi T, Akiyama M. 1989a. Photomicrographs of the Fresh-water algae. Vol. 9. Uchida Rokakuho, Tokyo.

Yamagishi T, Akiyama M. 1989b. Photomicrographs of the Fresh-water algae. Vol. 10. Uchida Rokakuho, Tokyo.

Yamagishi T, Akiyama M. 1995a. Photomicrographs of the Fresh-water algae. Vol. 14. Uchida Rokakuho, Tokyo.

Yamagishi T, Akiyama M. 1995b. Photomicrographs of the Fresh-water algae. Vol. 15. Uchida Rokakuho, Tokyo. 